\title{
GEREJA DAN PENDIDIKAN SENI MUSIK BAGI ANAK
}

\author{
Ariel Januar Chrisnahanungkara \\ Universitas Negeri Semarang \\ chrisnahanungkara@ymail.com
}

\begin{abstract}
Abstrak
Tujuan penelitian ini adalah memahami pentingnya melaksanakan pendidikan musik oleh gereja. Penelitian ini menjelaskan mengenai pentingnya pendidikan seni bagi manusia, kehidupan seni yang ada dalam gereja serta proses pendidikan seni yang pernah terjadi dalam gereja. Secara khusus penelitian ini mengingatkan kembali kepada kita bahwa gereja tidak boleh mengabaikan pendidikan musik di gereja dalam upaya menjaga tradisi yang dimiliki oleh gereja.
\end{abstract}

Kata kunci: anak; gereja; pendidikan seni musik

\begin{abstract}
The purpose of this study is to understand the importance of carrying out music education by the church. This study explains the importance of art education for humans, the life of art in church and the process of art education that has been occurred in church. In particular, this study reminds us that church should not ignore music education in the church in an effort to maintain the church traditions.
\end{abstract}

Keywords: child; church; music art education

\section{Pendahuluan}

Manusia merupakan makhluk yang berbudaya. Peradaban manusia dipengaruhi dengan perkembangan ilmu pengetahuan, teknologi dan seni. Perkembangan yang terjadi dalam kehidupan masyarakat menjadi tanda sejauh mana peradaban manusia mengalami kemajuan.

Perkembangan ilmu pengetahuan, teknologi dan seni menimbulkan perubahan kebudayaan manusia. Kebudayaan secara antropologi dapat diartikan sebagai keseluruhan sistem gagasan, tindakan dan hasil karya manusia dalam kehidupan masyarakat yang menjadikan milik diri manusia dengan belajar (Koentjaraningrat, 2015, p. 144). Manusia sebagai makhluk budaya membentuk budayanya dari gagasan, tindakan dan hasil karya manusia. Teknologi, ilmu pengetahuan dan seni merupakan hasil dari gagasan dan karya manusia. Kemajuan ipteks mengharuskan manusia untuk bertindak sebagai wujud adaptasi dalam kemajuan peradabannya. Manusia beradaptasi dengan lingkungannya melalui pendidikan.

Pendidikan memiliki peran penting dalam kebudayaan manusia. Pendidikan merupakan upaya membudayakan manusia dengan segala sifat kemanusiaannya (Triyanto, 
2016, p. 1). Manusia diberi kemampuan untuk berpikir secara logika, etika dan estetika dalam menjalani kehidupannya. Pendidikan mampu memaksimalkan potensi dan sifat alami manusia sehingga manusia dapat beradaptasi dengan lingkungannya dan memenuhi kebutuhan manusia memanfaatkan logika, etika dan estetikanya. Manusia yang tidak mampu memaksimalkan potensi yang dimilikinya akan kesulitan memenuhi kebutuhannya di zaman yang serba maju saat ini.

Manusia mengalami pendidikan sejak manusia lahir. Manusia memiliki tiga lembaga pendidikan berupa lembaga pendidikan secara formal, informal dan non formal. Pendidikan melalui lembaga informal menjadi lembaga pendidikan pertama dimana keluarga menanamkan nilai yang harus dihidupi. Pendidikan secara formal ditempuh manusia dalam sebuah lembaga yang memiliki aturan-aturan yang jelas. Pendidikan secara formal dilakukan melalui lembaga formal pendidikan usia dini sampai kepada perguruan tinggi. Pendidikan non formal dialami manusia dalam lingkungan masyarakat. Pendidikan non formal menolong individu untuk belajar mengenai nilai dan tatanan sosial yang berlaku di lingkungan masyarakat yang bersangkutan.

Pendidikan yang ada di lembaga formal Indonesia lebih banyak mementingkan aspek rasionalitas dalam manusia. Fenomena ini tampak jelas dimana pendidikan formal memberikan porsi yang lebih untuk mata pelajaran yang mengandalkan logika. Pendidikan seni yang mengandalkan rasa dan estetika seakan-akan dikesampingkan dalam pendidikan formal. Seni tidak mendapatkan tempat yang spesial dalam pendidikan di lembaga formal karena pendidikan seni tidak berfokus meningkatkan aspek kognitif. Terbatasnya pelaksanaan pendidikan seni dalam lembaga formal di Indonesia membuat pendidik berpikir secara serius demi pemaksimalan potensi manusia.

Manusia yang potensinya tidak terasah secara maksimal akan mengalami kesulitan dalam menjalani kehidupannya. Aspek kognitif manusia yang terlalu dibesar-besarkan dalam pendidikan formal membuat manusia bisa kehilangan nilai-nilai yang harus dihidupi. Manusia bisa menjadi individu yang baik secara kognitif tetapi belum menjamin menjadi manusia yang baik secara moral dan etika.

\section{Pendidikan dalam Kehidupan Manusia}

Pendidikan membuat individu dapat mempelajari pranata-pranata sosial, simbolsimbol dan nilai-nilai yang dapat menjadi pedoman bertingkah laku yang bermakna bagi individu yang bersangkutan dalam kehidupan masyarakatnya (Triyanto, 2017, p. 78). 
Manusia akan menemukan simbol dan nilai-nilai yang menjadi pedoman masyarakat kebudayaan yang dihidupi. Kebudayaan manusia berjalan secara dinamis diakibatkan oleh perkembangan iptek. Manusia sebagai makhluk budaya perlu berpikir dengan cermat supaya dapat menempatkan diri dengan baik dalam menanggapi perkembangan zaman.

Pendidikan dalam kaitannya dengan budaya menolong individu dalam beradaptasi dengan lingkungan di sekitarnya melalui pembudayaan/ enkulturasi. Pendidikan sebagai saluran pembudayaan memiliki tiga peranan penting yaitu education as cultural conservation, education as cultural regression, education as cultural transition (Syaripudin \& Kurniasih, 2008). Pendidikan sebagai proses budaya memiliki peranan untuk menjaga kebudayaan yang sudah ada dalam masyarakat, pendidikan juga berperan besar dalam melihat budaya masa lalu yang pernah berkembang dalam masyarakat sehingga masyarakat mendapatkan nilai yang baru dan pendidikan menolong masyarakat mengalami peralihan kebudayaan.

Pendidikan memiliki pembelajaran yang pelaksanaannya mencakup aspek kognitif, afektif dan psikomotorik. Pendidikan menjadi sarana yang tepat dalam upaya pengoptimalan potensi manusia dengan cara menyeimbangkan aspek kognitif, afektif dan psikomotorik. Pelaksanaan pendidikan di lembaga formal yang banyak dijumpai di Indonesia menghadapi masalah yang besar diakibatkan ketidakseimbangan dalam melaksanakan dan mengaplikasikan ketiga aspek di atas. Pendidikan di Indonesia seakanakan direncanakan hanya untuk mementingkan aspek kognitif. Pendidikan difokuskan kepada mata pelajaran yang mencakup aspek kognitif, sehingga pelaksanaan mata pelajaran yang beraspek kognitif mendapatkan porsi yang lebih. Pendidikan yang lebih mementingkan aspek kognitif akan membuat peserta didik mengalami kelelahan dan kejenuhan ketika belajar.

Pendidikan yang menghabiskan banyak waktu dalam pengembangan aspek kognitif dan mengarahkan pengembangan kemampuan yang bersifat rasionalistik akan membuat manusia mengalami kemunduran. Pendidikan semacam ini membuat manusia tidak dimanusiakan karena potensi yang dimiliki tidak dikembangkan secara utuh. Aspek afektif dan psikomotorik dalam pendidikan perlu dilaksanakan demi memanusiakan manusia. Pendidikan seni menjadi salah satu penolong bagi masyarakat dalam memanusiakan manusia baik dilakukan dalam lembaga informal, formal dan non formal. 


\section{Seni dan Pendidikan Seni bagi Kehidupan Manusia}

Seni merupakan salah satu unsur kebudayaan manusia. Manusia sebagai makhluk budaya dapat mewujudkan seni baik dalam ide, aktivitas maupun artefak. Manusia tidak bisa melihat seni yang berwujud ide secara konkret karena seni itu hidup dalam pikiran manusia tersebut. Manusia bisa melihat seni yang berwujud aktifitas dari pola perilaku manusia ketika berkesenian. Manusia bisa melihat seni yang berwujud artefak dari hasil fisik dari aktifitas dan karya manusia dalam berkesenian.

Sumardjo (Sumardjo, 2000) memberikan pencerahan kepada kita mengenai seni. Seni memiliki wujud berupa ekspresi, benda, nilai dan pengalaman. Seni berwujud ekspresi berarti seni sebagai ungkapan manusia dalam menguasai, mengatur dan mengelola perasaannya. Seni berwujud benda berarti seni merupakan wujud yang dapat dilihat atau didengar atau dilihat dan didengar secara sekaligus oleh penikmat seni. Seni berwujud nilai berarti seni memiliki nilai yang ingin dibagikan kepada penikmat seni. Seni berwujud pengalaman berarti seni memberikan kepada penikmat seni sebuah pengalaman yang berbeda dengan pengalaman yang berbeda dengan pengalaman sehari-hari.

Seni yang dikemukakan oleh Sumardjo bisa dikaitkan dengan seni sebagai wujud kebudayaan. Seni berupa nilai dan pengalaman saya katakan sebagai seni yang mewujud dalam ide. Manusia tidak bisa melihat seni sebagai nilai dan pengalaman karena nilai dan pengalaman yang terkandung dalam seni tidak bisa dilihat secara kasatmata. Seni berupa ekspresi saya katakan sebagai seni yang mewujud dalam aktifitas. Pola perilaku manusia dalam berkesenian akan nampak ketika manusia mengekspresikan keseniannya. Seni berupa bentuk saya katakan sebagai seni yang mewujud dalam artefak. Manusia dapat melihat artefak dalam bentuk seni yang bisa dilihat atau didengar atau dilihat dan didengar sekaligus.

Kemajuan peradaban manusia dianggap maju dilihat dari kemajuan ilmu pengetahuan, teknologi dan seni. Ilmu pengetahuan, teknologi dan seni tidak bisa dilepaskan satu sama lain karena semua unsur penting dan jika salah satu unsur tidak mendapatkan perhatian maka manusia dapat kehilangan nilai yang berlaku dalam tatanan sosialnya. Seni menolong manusia tidak hanya sebagai alat bantu untuk memosisikan manusia sebagai manusia yang utuh melainkan juga menolong manusia untuk mengalami kemajuan peradaban.

Seni menjadi penyeimbang kehidupan masyarakat dikala ilmu pengetahuan dan teknologi terus berkembang. Ilmu yang berkembang pesat tanpa dukungan seni dapat 
membuat manusia hanya mendapat nilai secara kognitif, seni berperan memberikan nilainilai yang tidak didapat dalam pengetahuan seperti moral. Teknologi yang berkembang pesat tanpa dukungan seni membuat teknologi yang maju terkesan monoton, seni berperan memberikan dan memunculkan nilai-nilai keindahan di setiap bentuk perkembangan teknologi.

Seni yang mewujud dalam nilai sering dikaitkan dengan nilai keindahan (estetika). Pendidikan seni bisa dikatakan sebagai pendidikan estetika. Pendidikan seni sebagai pendidikan estetika menolong manusia untuk melatih kesadaran moral dan mental (Pamadhi, 2012, p. 50). Manusia dalam berbudaya harus bertindak dalam kesadaran moral dan mental. Kesadaran moral dan mental penting bagi kehidupan manusia dalam bermasyarakat karena kesadaran moral menjadi rambu bagi manusia menanggapi perubahan zaman yang berjalan.

Seni sebagai penyeimbang kemajuan kehidupan manusia perlu dimiliki bahkan dihidupi oleh masyarakat sebagai warisan budaya. Seni memiliki wujud ekspresi, nilai, bentuk dan pengalaman diharapkan bukan hanya milik satu individu saja melainkan seni menjadi milik umum. Kepemilikan seni secara umum akan membuat ekspresi, nilai, bentuk dan pengalaman seni tidak mudah hilang.

Pendidikan seni mengambil peran yang penting dalam rangka membuat seni menjadi milik umum. Pendidikan seni menjadi sarana pembudayaan sehingga seni yang mewujud dalam ekspresi, nilai, bentuk dan pengalaman dapat dilestarikan, diwariskan bahkan bisa dikembangkan dari individu ke individu, dari kelompok ke kelompok dan yang penting dari generasi ke generasi. Pendidikan seni tidak sekedar sebuah proses pelestarian melainkan pendidikan seni juga menjadi proses regresi dalam rangka pencarian nilai yang baru dari kesenian yang pernah berkembang dalam masyarakat. Penemuan nilai yang baru akan menolong masyarakat melakukan transisi ketika menampilkan kesenian yang baru.

\section{Gereja, Seni Musik dan Pendidikan Seni Musik}

Gereja secara etimologi berasal dari bahasa Yunani yaitu ekklesia yang berarti mereka yang dipanggil keluar. Selatang memberikan pengertian menarik bahwa gereja merupakan sebuah paguyuban dimana memiliki persekutuan orang beriman dan ada partisipasi antar anggota dalam membangun persekutuan itu (Selatang, 2017, p. 57). Gereja menjadi komunitas dari orang-orang yang dipanggil untuk membangun iman. Gereja 
melaksanakan pembelajaran iman melalui kegiatan perenungan Firman Tuhan. Mutak mengatakan bahwa gereja sebagai agen pendidikan Kristen (Mutak, 2005, p. 19). Gereja yang berperan sebagai agen pendidikan tidak sekedar melaksanakan pendidikan Kristen yang berkaitan dalam spiritualitas, gereja juga berperan sebagai agen pendidikan seni khususnya seni musik dimana aktifitas ibadah orang kristen tidak bisa dipisahkan dari musik.

Gereja sebagai sebuah lembaga nonformal memiliki kehidupan seni. Seni musik hadir dalam kehidupan gereja melalui ibadah dan musik menjadi sarana bagi manusia untuk berkomunikasi dengan Tuhannya. Musik hadir dalam ibadah dan menjadi sarana bagi manusia mengekspresikan hatinya yang dapat meluapkan rasa syukur, kepedihan, butuh pertolongan dan butuh pengharapan. Segala ekspresi yang diluapkan manusia menggunakan media musik disusun menjadi sebuah rangkaian. Beberapa aliran gereja menyusun ekspresi yang dimiliki manusia sehingga musik dihadirkan dalam sebuah liturgi yang sistematis dimana liturgi tersebut memiliki bagian-bagian untuk mengekspresikan rasa syukur, penyesalan akan dosa, ketenangan setelah mendengar pengharapan. Aktifitas mengekspresikan hati manusia melalui seni menjadi sebuah kehidupan seni musik dalam gereja yang tetap terjaga hingga zaman sekarang.

Kehadiran seni musik dalam gereja selayaknya disadari oleh masyarakat gereja sebagai kebudayaan yang dimiliki oleh masyarakat gereja. Musik dalam gereja berwujud sebagai ide-ide yang bisa digagas. Musik dalam gereja juga mewujud dalam aktifitasaktifitas yang pada masa saat ini muncul dalam kegiatan masyarakat gereja berupa aktifitas memuji Tuhan dan menggunakan instrumen musik untuk mengiringi ibadah. Musik dalam gereja juga mewujud dalam artefak berupa karya-karya musik gereja yang bisa dimainkan atau dinyanyikan, contohnya misa, kantata, oratorio, karya koral, himne maupun lagu rohani kontemporer.

Musik dalam gereja mewakili sebuah kebudayaan yang dimiliki oleh masyarakat gereja. Pada awal abad pertengahan terjadi kebangkitan biara dan musik turut mengambil bagian dalam aktifitas ibadah. Musik gereja awalnya adalah sebuah kesaksian yang dipasang dalam musik dan diorganisasikan ke dalam sebuah liturgi (Forney \& Machlis, 2011, p. 75). Gereja di awal pertengahan memiliki sebuah nyanyian dan diorganisasikan menjadi sebuah misa yang dinyanyikan dalam ibadah. Musik gereja yang mewujud dalam aktifitas pada awalnya merupakan sebuah aktifitas bernyanyi yang dilakukan oleh beberapa orang yang melayani dalam misa di gereja katolik. Perubahan penting aktifitas seni musik 
dalam gereja dipengaruhi oleh reformasi Luther. Aktifitas musik gereja masa kini dipengaruhi oleh reformasi Marthin Luther dimana aktifitas bernyanyi boleh dilakukan semua masyarakat gereja bukan lagi aktifitas khusus yang dilakukan oleh beberapa orang dalam ibadah kristen, melainkan semua manusia yang ada dalam gereja diperbolehkan untuk bernyanyi (McNeill, 1998, p. 101). Reformasi Luther memberikan nilai baru mengenai pentingnya manusia dalam aktifitas ibadah. Reformasi Luther membuat manusia harus berinteraksi secara aktif dalam ibadah karena semua manusia dalam gereja dianggap sebagai subjek yang ikut serta dalam bernyanyi.

Musik gereja yang mewujud dalam aktifitas manusianya membawa perubahan kepada bentuk karya yang menjadi peninggalan masyarakat. Karya musik gereja awalnya berupa misa yang didasarkan kepada nyanyian gregorian yang dinyanyikan oleh pelayan ibadah dalam misa gereja katolik. Gereja yang dipengaruhi oleh reformasi Martin Luther memiliki karya baru berupa nyanyian yang dapat dinyanyikan oleh masyarakat gereja. Martin Luther membuat mazmur-mazmur dan lagu yang berbahasa Jerman sehingga jemaat bisa memahami dan menyanyikan nyanyian.

Musik gereja menjadi kebudayaan yang khusus yang dimiliki oleh masyarakat dalam gereja. Musik gereja dilestarikan dan dikembangkan oleh masyarakat gereja. Masyarakat sebagai pemilik kebudayaan membudayakan musik gereja dari generasi ke generasi melalui pendidikan musik.

Pendidikan seni musik melalui lembaga gereja dilaksanakan sejak zaman pertengahan dimana gereja bekerja sama dengan sekolah. Pendidikan musik di gereja di abad pertengahan diikuti oleh anak laki-laki (Kamien, 2010). Anak-anak dididik dalam gereja dan mereka juga melayani dalam gereja sebagai penyanyi kor. Di biara, para biarawati juga mengaami pendidikan musik Beberapa tokoh musik zaman pertengahan hingga zaman klasik mengalami pendidikan musik dalam gereja ataupun sekolah yang bekerja sama dengan lembaga gereja. Pendidikan musik pada zaman pertengahan hingga klasik membimbing anak-anak dalam teori musik, kontrapung, komposisi, bernyanyi dan memainkan instrumen.

Pendidikan musik zaman pertengahan hingga klasik memberikan gambaran mengenai proses pembudayaan dalam upaya menjaga tradisi gereja dimana aktifitas menyanyi dalam ibadah dilakukan oleh pelayan di gereja.

Gereja sebagai agen pendidikan nonformal memiliki misi penting dalam rangka menolong manusia menjadi manusia yang utuh. Gereja kristen memiliki aktifitas bernyanyi 
sebagai proses interaksi yang aktif antar manusia dalam gereja. Interaksi aktif dalam kegiatan bernyanyi membuat manusia secara sadar maupun tidak sadar mengasah dan mengembangkan keterampilannya dalam hidup bersosial. Interaksi aktif dalam ibadah merupakan sebuah warisan penting yang ditinggalkan oleh reformasi Luther. Gereja perlu menyadari sebuah warisan penting dalam gereja sehingga gereja harus menjaga warisan ini. Gereja perlu melaksanakan pendidikan sebagai sebuah upaya konservasi dalam menjaga warisan penting ini. Gereja perlu menanamkan nilai pentingnya interaksi aktif dalam ibadah melalui kegiatan bermusik (menyanyi maupun memainkan instrumen) sehingga aktifitas gereja di masa mendatang tetap memiliki ibadah yang mempertahankan interaksi aktif antar manusia dalam gereja.

\section{Pendidikan Seni Musik dalam Gereja Saat Ini}

Gereja masa kini (tidak dibatasi oleh denominasi tertentu) memiliki kehidupan musik yang mewujud dalam aktifitas bernyanyi dan mengiringi nyanyian jemaat serta mewujud dalam karya-karya lagu nyanyian jemaat. Gereja menjadi lembaga pendidikan nonformal yang mau tidak mau harus mengajarkan kepada peserta didik mengenai musik gereja sebagai budaya yang diwujudkan dalam ide, aktifitas dan artefak.

Pendidikan seni musik dalam gereja dianggap sebagai proses yang penting dalam gereja. Gereja menjadi lembaga pendidikan yang mengajarkan generasi penerus gereja (anak-anak) mengenai bernyanyi dan memainkan instrumen yang menjadi aktifitas tetap dalam kehidupan bergereja. Pendidikan musik perlu dilakukan oleh gereja dalam rangka membiasakan generasi penerus gereja untuk menyanyi dan memainkan instrumen dalam peribadahan baik ketika berperan sebagai jemaat maupun pelayan ibadah. Karya musik gereja baik berbentuk nyanyian koor maupun nyanyian jemaat dijadikan bahan ajar bagi peserta didik untuk menolong peserta didik membiasakan diri terhadap aktifitas yang dilakukan dalam ibadah kristen.

Anak-anak dan remaja merupakan ujung tombak bagi kehidupan gereja di masa mendatang. Fudyartanta mengutip Aristoteles (Fudyartanta, 2011, p. 83) menggolongkan masa anak sebagai fase dimana manusia berusia tujuh sampai empat belas tahun. Fudyartanta mengutip Piaget (Fudyartanta, 2011, p. 89) yang mengatakan secara kognitif anak berumur tujuh hingga empat belas tahun memiliki kemampuan untuk berpikir logis dan menguasai percakapan. Gereja perlu mengambil tindakan penting dalam rangka menanggapi potensi besar yang dimiliki oleh anak-anak. Gereja perlu melaksanakan 
pendidikan seni bagi anak meskipun secara nonformal. Perkembangan dan potensi yang dimiliki oleh anak perlu digarap secara serius oleh gereja.

Gereja sebagai agen pendidikan seharusnya mengambil peran dalam upaya menjaga warisan yang dimiliki gereja. Edukasi kepada anak sebagai ujung tombak gereja dilakukan dalam rangka menjaga dan menanamkan nilai yang dimiliki oleh gereja, baik itu nilai secara religius, etis maupun estetis. Gereja perlu melakukan pendidikan seni seefektif mungkin agar kebudayaan gereja yang mewujud dalam ide, aktifitas maupun artefak tetap terjaga.

Pendidikan seni musik dalam gereja turut mengambil peran dalam upaya memanusiakan manusia. Pendidikan melalui seni yang dilaksanakan dalam gereja menolong anak untuk menyeimbangkan potensi yang dimiliki. Gereja memiliki andil dalam mengasah serta meningkatkan aspek estetis dan etis yang mungkin tidak banyak disentuh dalam pendidikan secara formal. Interaksi aktif dalam peribadahan kristen menjadi aktifitas penting sebagai upaya penyadaran bahwa manusia merupakan makhluk sosial yang perlu berinteraksi. Kegiatan-kegiatan seni dalam gereja akan menolong anak untuk meningkatkan aspek estetis.

Pendidikan seni musik dalam gereja dilaksanakan melalui kegiatan seni berupa ekspresi, apresiasi dan kreasi demi penanaman nilai-nilai terhadap peserta didik. Kegiatan ekspresi dalam pelaksanaan pendidikan seni musik di gereja dilaksanakan dalam rangka mengekspresikan aktifitas maupun karya musik yang dimiliki oleh gereja. Kegiatan ekspresi dilakukan anak melalui interaksi aktif ketika bernyanyi dalam ibadah. Kegiatan ekspresi juga bisa ditambahkan ketika anak diberi tambahan waktu di luar ibadah untuk belajar musik di gereja. Kegiatan ekspresi menjadi aktifitas yang penting agar anak sebagai manusia yang mampu berinteraksi secara aktif memiliki kepercayaan diri dalam melakukan interaksi dalam ibadah maupun interaksi di luar gereja.

Kegiatan apresiasi dalam pendidikan seni musik di gereja dilaksanakan dalam rangka memberi nilai terhadap aktifitas musik dan karya musik yang berkembang. Gereja dapat mengalami fenomena dimana generasi anak sekarang enggan menyanyikan lagu anak generasi sebelumnya dalam ibadah anak. Di sisi lain kemajuan ipteks membuat karya musik gereja menjadi lebih kaya karena ada komposisi baru maupun lama yang disajikan dalam berbagai genre musik. Kegiatan apresiasi perlu dilaksanakan untuk mencari nilai yang dikandung dalam musik yang disajikan. Nilai yang sudah ditemukan akan menjadi nilai yang dibagikan dan ditanamkan kepada anak sehingga mereka tidak enggan dan 
mampu berekspresi ketika menyanyi. Kegiatan apresiasi tidak sekedar mencari nilai yang terkandung dalam lagu yang dinyanyikan, melainkan apresiasi juga menanamkan nilai menghargai kepada anak.

Kegiatan kreasi dalam pendidikan seni musik di gereja dilaksanakan dalam rangka mengasah dan mengembangkan kreativitas yang dimiliki oleh anak. Masa anak merupakan masa dimana anak suka berimajinasi. Seni dapat digunakan sebagai sarana untuk mengekspresikan imajinasi anak. Imajinasi anak perlu diwadahi dengan kegiatan kreasi dan anak dibebaskan untuk berkreasi. Kegiatan kreasi anak masa sekarang didukung dengan perkembangan ipteks yang menjadi alat bantu bagi anak untuk menyusun ide-ide. Kegiatan kreasi membuat anak mampu menciptakan kebaruan yang akan mempengaruhi kehidupan gereja ke depan.

Pendidikan seni musik di gereja yang dilaksanakan melalui aktifitas ekspresi, apresiasi dan kreasi menolong penyeimbangan potensi anak yang mungkin tidak dapat diasah secara maksimal melalui pendidikan formal. Pendidikan seni musik di gereja tidak hanya sebuah proses pembudayaan dan penanaman nilai yang dimiliki oleh gereja. Pendidikan seni musik di gereja secara tidak langsung menolong anak untuk memaksimalkan potensinya sebagai manusia. Gereja perlu mengasah dan mengembangkan aspek estetis dan etis anak.

Pelaksanaan pendidikan seni di gereja bukanlah proses yang mudah. Berbagai kendala dialami oleh gereja dalam rangka melaksanakan pendidikan musik, diantaranya tidak tersedianya pendidik, sarana prasana yang belum memadai hingga tidak tersedianya sumber daya. Kendala yang dimiliki gereja seharusnya menjadi kegelisahan yang harus dipikirkan dan gereja perlu mencari jalan keluar sebagai lembaga pendidikan non formal.

Gereja sebagai lembaga pendidikan seringkali kekurangan generasi penerus dalam aktifitas seni di gereja (pemain instrumen maupun penyanyi). Gereja perlu bekerja keras mencari bibit agar menjadi peserta didik seni. Seberapa pun yang dimiliki gereja perlu dijaga demi kelangsungan aktifitas musik dalam gereja di masa mendatang. Gereja perlu memiliki orang yang mampu menjadi pendidik musik. Banyak gereja yang memiliki orang yang belajar musik secara mandiri tanpa belajar di sebuah lembaga pendidikan. Orang seperti ini perlu dilibatkan dalam pendidikan seni musik di gereja. Bagi gereja yang memiliki kemampuan secara finansial perlu mengirim orang untuk mengalami pendidikan seni di lembaga formal maupun nonformal sehingga orang itu dapat membagikan ilmu 
kepada orang lain di gereja. Gereja yang tidak memiliki orang yang berpotensi menjadi pendidik perlu mendatangkan pendidik seni demi kelangsungan pendidikan seni di gereja.

\section{Kesimpulan}

Gereja memiliki andil yang penting dalam memanusiakan manusia dan membuat manusia memiliki keseimbangan pola pikir secara logika, etika dan estetika. Pendidikan musik di gereja menjadi sarana menyeimbangkan ketidakseimbangan yang dimiliki oleh anak akibat penekanan aspek kognitif yang didapat dalam pendidikan formal. Gereja saat ini perlu memiliki kesadaran akan pentingnya pendidikan seni musik bagi anak dan gereja perlu mengambil peran dalam pendidikan seni. Kesadaran yang dimiliki gereja tidak hanya menolong individu saja melainkan akan menolong gereja sebagai sebuah masyarakat dapat melakukan setiap aktifitas musik di gereja. Gereja perlu menghadirkan pendidikan seni di gereja dalam rangka menjaga dan membudayakan kebudayaan yang dimiliki gereja. Gereja perlu melakukan aktifitas ekspresi, apresiasi dan kreasi dalam pendidikan seni. Gereja dengan segala sumber daya yang dimilikinya perlu bekerja keras mencari anak sebagai peserta didik dan mencari orang yang bisa dijadikan pendidik seni. Pendidikan seni yang dilaksanakan di gereja diharapkan menolong manusia yang ada dalam gereja untuk memaksimalkan dan menyeimbangkan potensi yang dimiliki.

\section{Kepustakaan}

Forney, K., \& Machlis, J. (2011). The Enjoyment of Music (11th ed.). New York: W. W. Norton \& Company, Inc.

Fudyartanta, K. (2011). Psikologi Perkembangan. Yogyakarta: Pustaka Belajar.

Kamien, R. (2010). Music an Apreciation. New York: McGraw-Hill Companies.

Koentjaraningrat. (2015). Pengantar Ilmu Antropologi (Kesepuluh). Jakarta: PT Rineka Cipta.

McNeill, R. J. (1998). Sejarah Musik 1. Jakarta: BPK Gunung Mulia.

Mutak, A. A. (2005). Gereja dan Pendidikan Kristen. Jurnal Theologia Aletheia, 7(12), $13-23$.

Pamadhi, H. (2012). Pendidikan Seni (Hakikat Kurikulum Pendidikan Seni, Habitus Seni, dan Pengajaran Seni Anak. Yogyakarta: UNY Press.

Selatang, F. (2017). Gereja Musafir Sebagai Antisipasi Hidup Eskatologis. JUMPA, V(2), $55-66$.

Sumardjo, J. (2000). Filsafat Seni. Bandung: Penerbit ITB. 
Syaripudin, T., \& Kurniasih. (2008). Pengantar Filsafat Pendidikan. (P. Ilmu, Ed.). Bandung.

Triyanto. (2016). Paradigma Humanistik dalam Pendidikan Seni. Imajinasi, X(1), 1-10. Retrieved from https://journal.unnes.ac.id/nju/index.php/imajinasi/article/view/8811/5774

Triyanto. (2017). Spirit Ideologis Pendidikan Seni. Semarang: Cipta Prima Nusantara. 